\title{
Isolasi Mandiri Covid-19 dengan Daring PjBL Berbasis Mind Mapping untuk Meningkatkan Hasil Belajar Biologi
}

\author{
Ni Luh Ratna Tirtawati* \\ SMA Negeri 1 Semarapura, Klungkung, Indonesia
}

A R T I C L E I N F O

Article history:

Received 19 August 2020

Received in revised form

30 September 2020

Accepted 10 October 2020

Available online 29

November 2020

\section{Kata Kunci:}

Projek Based Learning

Mind Mapping dan Hasil

Belajar

Keywords:

Project Based Learning

Mind Mapping and Biology

Learning Achievement

\begin{abstract}
A B S T R A K
Penelitian ini bertujuan Untuk mengetahui penerapan Projek Based Learning ( $\mathrm{PjBL}$ ) Berbasis Mind Mapping dapat meningkatkan hasil belajar biologi dikelas XI di masa isolasi mandiri Covid-19. Subjek penelitian ini berjumlah 36 Orang dengan rincian 19 Orang peserta didik Perempuan dan 17 Orang peserta didik Laki-laki. Objek penelitian berupa hasil belajar biologi. Penelitian ini dilaksanakan dalam dua siklus, semua sintak model pembelajaran PjBL Berbasis Mind Mapping dilakukan secara daring melalui aplikasi WhatsApp dan proses evaluasi pembelajaran Biologi dengan menggunakan aplikasi quizizz. Hasil yang diperoleh untuk hasil belajar biologi mengalami peningkatan dari siklus I ke siklus II, dari rata-rata Accuracy $67.94 \%$ menjadi $85.93 \%$ dengan persentase tuntasan $38.89 \%$ menjadi $88.89 \%$. Kesimpulan Penerapan Projek Based Learning (PjBL) Berbasis Mind Mapping dapat meningkatkan hasil belajar Biologi di Kelas di masa isolasi mandiri Covid-19.
\end{abstract}

\section{A B S T R A C T}

This class action research's purpose is to measure the Implementation of Project Based Learning (PjBL) Based on Mind Mapping for Improving Biology Learning Achievement in XI MIPA 2 Class of SMA Negeri 1 Semarapura Even Semester Academic Year 2019/2020 during the Independent Self Isolation Covid-19. The subject of this study is 36 students, consists of 19 female and 17 male students. The object of research is Biology Learning Achievement. This research was carried out in two cycles, all the syntax of PjBL learning model based on Mind Mapping were conducted online through the WhatsApp application and the Biology learning process evaluated by using quizizz application. The results obtained for learning achievement increased from cycle I to cycle II, from an average accuracy of $67.94 \%$ to $85.93 \%$ with a percentage of completion $38.89 \%$ to 88.89\%. In Conclusion, the Implementation of Mind Based Mapping Based Projects (PJBL) can improve Biology learning achievement in Class XI MIPA 2 of SMA Negeri 1 Semarapura Even Semester Academic Year 2019/2020 during the Independent Self Isolation Covid-19.

\section{Pendahuluan}

Saat ini pendidikan dianggap sebagai suatu aktifitas yang diarahkan untuk menyongsong perkembangan-perkembangan yang diperhitungkan akan terjadi di masa depan. Hal ini membuat dunia pendidikan dituntut untuk merancang sistem pendidikan yang lebih kreatif, dinamis dan responsif terhadap perubahan serta kecenderungan-kecenderungan yang sedang berlangsung. Untuk mencapai tujuan pendidikan nasional maka dikembangkan berbagai model pembelajaran dalam proses pendidikan yang setiap saat mengalami perkembangan. sampai saat ini beberapa model pembelajaran yang di rekomendasikan dalam kurikulum 2013 menggunakan metode tatap muka. Tapi saat ini situasinya berbeda, dunia pendidikan di Indonesia mulai mengalami gangguan semenjak Covid-19 sudah mulai 
menginfeksi masyarakat Indonesia, dimana kita tau bahwa virus corana yang sekarang lebih dikenal dengan nama Covid-19 mulai menjangkiti masyarakat Wuhan, Cina dan terus menyebar ke seluruh dunia dan sampai juga di Indonesia. Serangan Covid-19 tidak hanya berpengaruh pada dunia industri, tenaga kerja, tapi juga dunia pendidikan. Semenjak ada edaran yang dikeluarkan Presiden Indonesia, dilanjutkan dengan edaran Menteri dan Gubenur Bali, maka sejak tanggal 16 Maret 2020 sekolah diliburkan, dan proses pembelajaran dilakukan dengan metode daring, hal ini dilakukan sebagai upaya untuk mencegah meluasnya Covid-19 di masyarakat. Upaya ini dilakukan agar siswa tetap memahami materi yang harus mereka kuasai di semester II tahun pelajaran 2019/2020 tapi tidak membebani siswa yang sudah dalam situasi tidak nyaman. Jadi diharafkan model pembelajaran dapat membuat siswa tetap ada di rumah untuk mencegah penyebaran Covid-19 tapi tetap bisa belajar dengan menyenangkan. Maka banyak yang dilkukan oleh guru dalam proses pembelajaran. pemilihan Metode yang tepat sangat dibutuhkan agar tujuan dari pemebajaran terhujud.

Menurut (Prastyo, 2016) salah satu cara yang dilakukan dalam menyampaikan pembelajaran yaitu metode. Kendala tidak tercapainya sebuah tujuan pembelajaran tergantung pada penggunaan metode yang tidak sesuai dengan tujuan. Seorang guru dituntut untuk membuat proses pembelajaran menarik dengan menggunakan metode yang akan membuat peserta didik terlibat dalam pembelajaran dan berkreativitas. Pemilihan metode harus disesuaikan dengan materi yang diajarkan, kondisi sekolah, dan kondisi peserta didik dan penyesuaian lainnya. Karena jika kita salah memilih metode yang tidak sesuai akan berdampak pada hasil yang kurang maksima Dengan adanya situasi darurat saat ini dan tuntutan bahwa proses pembelajaran harus dilakukan dengan daring maka penulis melakukan inovasi model pembelajaran dengan menerapkan model Projek Based Learning (PjBL) berbasis Mind Mapping.

Pembelajaran Berbasis Proyek (Project Based Learning=PjBL) menurut (Kemendikbud, 2014) adalah model pembelajaran yang menggunakan proyek/kegiatan sebagai inti pembelajaran. Sedangkan menurut Joel L dalam (Widyantini, 2014) Pembelajaran berbasis proyek adalah strategi pembelajaran yang memberdayakan siswa untuk memperoleh pengetahuan dan pemahaman baru berdasar pengalamannya melalui berbagai presentasi. PjBL merupakan model belajar yang menggunakan masalah sebagai langkah awal dalam mengumpulkan dan mengintegrasikan pengetahuan baru berdasarkan pengalamannya dalam beraktifitas secara nyata. Melalui PjBL, proses inquiry dimulai dengan memunculkan pertanyaan penuntun (a guiding question) dan membimbing siswa dalam sebuah proyek kolaboratif yang mengintegrasikan berbagai subjek (materi) dalam kurikulum. PjBL merupakan investigasi mendalam tentang sebuah topik dunia nyata, hal ini akan berharga bagi atensi dan usaha peserta didik. Adapun langkah-langkah PjBL: 1) Penentuan pertanyaan mendasar (Start With The Essention Question), 2) Mendesain perencanaan proyek (Design a Plan For The Project), 3) Menyusun jadwal (Create a Scedule), 4) Memonitor peserta didik dan kemajuan proyek (Monitor the Students and the Progress of the Project), 5) Menguji hasil (Assess the Outcome), dan 6) Mengevaluasi Pengalaman (Evaluate the Experience). Menurut Aisah (2014) Keuntungan Pembelajaran Berbasis Proyek: (1) Meningkatkan motivasi belajar peserta didik untuk belajar, mendorong kemampuan mereka untuk melakukan pekerjaan penting, dan mereka perlu untuk dihargai, (2) Meningkatkan kemampuan pemecahan masalah, (3) Membuat peserta didik menjadi lebih aktif dan berhasil memecahkan problem-problem yang kompleks, (4) Meningkatkan kolaborasi, (5) Mendorong peserta didik untuk mengembangkan dan mempraktikkan keterampilan komunikasi, (6) Meningkatkan keterampilan peserta didik dalam mengelola sumber, (7) Memberikan pengalaman kepada peserta didik pembelajaran dan praktik dalam mengorganisasi proyek, dan membuat alokasi waktu dan sumber-sumber lain seperti perlengkapan untuk menyelesaikan tugas, (8) Menyediakan pengalaman belajar yang melibatkan peserta didik secara kompleks dan dirancang untuk berkembang sesuai dunia nyata, (9) Melibatkan para peserta didik untuk belajar mengambil informasi dan menunjukkan pengetahuan yang dimiliki, kemudian diimplementasikan dengan dunia nyata, dan (10) Membuat suasana belajar menjadi menyenangkan, sehingga peserta didik maupun pendidik menikmati proses pembelajaran.

Mind mapping adalah cara mencatat yang efektif, efisien, kreatif, menarik, mudah dan berdaya guna karena dilakukan dengan cara memetakan pikiran-pikiran kita (Swadarma, 2013). Dalam bukunya (DePoter \& Hernacki, 2013), menyatakan ada dua teknik pencatatan sangat efektif yaitu mind mapping (peta pikiran) dan tulis susun, dimana kedua cara ini dapat membuat kita mampu melihat seluruh gambaran secara selintas, dan menciptakan hubungan mental yang membantu kita memahami dan mengingat. Para pengguna mind mapping dapat segera membedakan betapa rencana-rencana mereka lebih terarah. Dengan demikian membuat hidup mereka lebih berarti dan terencana dengan baik. mind mapping mengajarkan untuk fokus pada apa yang sedang dipikirkan dan direncanakan. Maka para pengguna mind mapping cenderung lebih sederhana cara berpikir dan kerjanya, karena mereka tak lagi tumpang tindih dalam menjalankan visi dan misinya. Pengguna mind mapping daya kreativitasnya cenderung meningkat, karena otak mereka ter-eksplor dengan baik. Belajar menggunakan Mind Mapping 
membuat siswa memiliki kebebasan untuk mengeksplorasi imajinasinya dalam membuat mapping yang dikaitkan dengan materi yang di berikan. Menurut (Nurani et al., 2014) model pembelajaran Mind Mapping sendiri merupakan sebuah strategi pembelajaran yang mengupayakan seorang peserta didik untuk menggali ide-ide kreatif dan aktif dalam mengikuti kegiatan pembelajaran dengan membuat gambar-gambar dan garis yang berwarna-warni agar lebih mudah untuk dihafal, sehingga pembelajaran yang dilakukanakan menjadi lebih hidup, variatif dan membiasakan siswa memecahkan permasalahan dengan cara memaksimalkan daya pikir dan kreativitas serta dapat membantu siswa menjadi lebih mandiri. Menurut (Syam \& Ramlan, 2015) pembelajaran Mind Map (peta pikiran) adalah model yang dirancang untuk membantu siswa dalam proses belajar, menyimpan informasi berupa materi pelajaran yang diterima oleh siswa pada saat pembelajaran, dan membantu siswa menyusun inti-inti yang penting dari materi pelajaran ke dalam bentuk peta, grafik maupun penggunaan simbol sehingga siswa lebih mudah mengingat pelajaran tersebut. Menurut (Hidayat et al., 2020) Mind Mapping merupakan salah satu metode pembelajaran dimana siswa mampu menjadi kreatif dalam menghasilkan suatu gagasan atau pikiran, mencatat apa yang harus dipelajari. Metode ini lebih menekankan pada pengkombinasian warna dan bentuk yang akan membuat siswa semakin tertarik dan bersemangat dalam proses pembelajaran, sehingga materi yang diserap dapat mudah dipahami.

Berdasarkan pada pemaparan diatas perlu diterapkan suatu model pembelajaran yang dapat merangkum semua teori yang telah disampaikan. Maka disini digunakan PjBL berbasis Mind Mapping untuk mengatasi proses pembelajaran daring dimasa pandemi Covid-19. Fokus permasalahan yang dicari jawabannya melalui penelitian ini dapat dirumuskan sebagai berikut: Apakah penerapan Projek Based Learning (PjBL) Berbasis Mind Mapping dapat meningkatkan hasil belajar biologi dikelas XI MIPA 2 SMA Negeri 1 Semarapura semester genap tahun pelajaran 2019/2020 di masa Isolasi mandiri Covid-19.

\section{Metode}

Penelitian ini merupakan penelitian tindakan kelas yang dilaksanakan pada semester genap Tahun pelajaran 2019/2020 di SMA Negeri 1 Semarapura. Lokasi sekolah sangat setrategis karena dekat dengan jalan raya yaitu beralamat di Jalan Plamboyan No 63 Semarapura sangat kondusif untuk belajar. Subjek penelitian adalah siswa kelas XI MIPA 2 yang berjumlah 36 orang dengan rincian 19 orang siswa perempuan dan 17 orang siswa laki-laki, sedangkan objek penelitian adalah hasil belajar biologi.

Penelitian ini dilaksanakan dalam dua siklus pembelajaran yang tiap siklusnya terdiri dari empat tahapan yaitu: 1) perencanaan tindakan, 2) pelaksanaan tindakan, 3) observasi dan evaluasi, dan 4) refleksi. Tahap perencanaan diisi dengan menyiapkan semua perangkat pembelajaran yang diperlukan diantaranya: a) menyusun RPP yang memiliki sintak PjBL berbasis mind mapping, b) menyusun LKS yang sesuai dengan sintak PjBL berbasis mind mapping, c) menyusun instrument penelitian, dan d) menyusun rubrik/pedoman penilaian. Tahapan pelaksanaan tindakan dilakukan sesuai dengan tahapan PjBL berbasis mind mapping yang dilaksankan secara daring. Adapun langkahnya a) menentukan kompetensi dasar yang ingin dicapai, b) melaksanakan kesepakatan lama waktu pengerjaan proyek mind mapping, c) melakukan proses pembelajaran secara daring. Observasi dilakukan sehingga setiap tindakan dalam pelaksanaan pembelajaran dapat terobservasi. Dari semua hasil observasi dilakukan evaluasi secara kontinyu untuk mengetahui ketepatan pelaksanaan tindakan dan kebermaknaan tindakan. Pada akhir siklus dilakukan tes mengunakan aplikasi quizziz secara daring guna memperoleh gambaran mengenai pemahaman konseptual siswa. Untuk menilai pemahaman siswa dilaksanakan tes untuk mengukur hasil belajar. Hasil tes dianalisis secara deskriptif, yaitu dengan menentukan skor rata-rata hasil tes kemudian dibandingkan dengan kriteria yang ada (konversi nilai). Refleksi dilakukan pada akhir siklus berdasarkan hasil dari analisis tes pada akhir siklus. hasil refleksi ini digunakan sebagai dasar penyempurnaan tindakan pada siklus selanjutnya sehingga kelemahan-kelemahan bisa diminimalissasi.

\section{Hasil dan Pembahasan}

Berdasarkan tujuan penelitian yang telah ditetapkan yaitu untuk mengetahui penerapan Projek Based Learning (PjBL) Berbasis Mind Mapping dapat meningkatkan hasil belajar biologi dikelas XI MIPA 2 SMA Negeri 1 Semarapura semester genap tahun pelajaran 2019/2020 di masa isolasi mandiri Covid-19. Untuk hasil belajar biologi pada siklus I yaitu perolehan hasil belajar biologi untuk Accuracy terendah yaitu $20 \%$ dan Accuracy tertinggi $100 \%$, dengan nilai rata-rata Accuracy peserta didik sebesar $67,94 \%$ dengan kategori kurang, jumlah peserta didik yang mencapai Accuracy $<75$ sebanyak 22 orang (61\%), sedangkan peserta didik yang mencapai Accuracy $\geq 75$ sebanyak 14 orang (39\%) dengan ketuntasan $38,89 \%$. Hasil ini menunjukkan bahwa ketuntasan secara klasikal belum tercapai, yaitu minimal sebesar 85\%. Perolehan hasil ini, tidak terlepas dari penerapan metode pembelajaran yang relatif baru, serta 
tuntutan hasil belajar yang lebih tinggi, karena menyangkut pemahaman secara komprehensif. Oleh karena itu, diperlukan strategi yang lebih efektif dan efisien dalam rangka meningkatkan hasil belajar biologi. Berdasarkan hasil refleksi Sikluas I bahwa Penerapan PjBL Berbasis Mind Mapping pada mata pelajaran biologi untuk bahan kajian tentang sistem reproduksi, belum berlangsung dengan baik yang mengakibatkan ketuntasan klasikal belum dapat tercapai, hal ini disebabkan oleh 4 (empat) hal: (1) Peserta didik belum terbiasa dengan proses pembelajaran melalui daring, sehingga mereka kebanyakan belum mandiri dalam membuat mapping tugas, masih sangat banyak memerlukan bimbingan; (2) Kemampuan siswa untuk mencari sumber materi di dunia maya masih perlu ditingkatkan terbukti dari kedalaman materi dalam mapping masih kurang; (3) Siswa belum maksimal dalam mengeksplorasi kemampuan imajinasinya sehingga mapping yang dihasilkan masih sederhana, dan (4) Hasil belajar belum maksimal kemungkinan karena siswa belum terbiasa menggunakan aplikasi quizizz dalam ulangan. Berdasarkan hasil refleksi siklus I maka dilakukan perencanaan siklus II yaitu penyiapan saran prasarana pendukung proses pembelajaran, penyusunan RPP dan LKS untuk siklus II dan lembar observasi siklus II. Hasil belajar dari proses siklus II yaitu yaitu perolehan hasil belajar biologi untuk Accuracy terendah yaitu 33\% dan Accuracy tertinggi 100\%, dengan nilai rata-rata Accuracy peserta didik sebesar 85.93\% dengan kategori kurang, jumlah peserta didik yang mencapai Accuracy <75 sebanyak 4 orang (11.11\%), sedangkan peserta didik yang mencapai Accuracy $\geq 75$ sebanyak 32 orang (88.89\%) dengan ketuntasan 88.89\%. Hasil ini menunjukkan bahwa ketuntasan secara klasikal sudah tercapai, yaitu lebih dari 85\%. Perolehan hasil ini terjadi karena siswa mulai terbisa dengan metode pembelajaran yang di terapkan. Hasil belajar peserta didik antara siklus I dan siklus II memperlihatkan peningkatan yang signifikan, itu bisa dilihat pada Tabel 1 .

Tabel 1. Perbandingan Hasil Belajar Biologi Peserta didik Siklus I dan Siklus II.

\begin{tabular}{lcc}
\hline \multicolumn{1}{c}{ Keterangan } & Siklus I & Siklus II \\
\hline Rata-Rata Accuracy (\%) & $67.94 \%$ & $85.93 \%$ \\
Accuracy Tertinggi (\%) & $100 \%$ & $100 \%$ \\
Accuracy terendah (\%) & $20 \%$ & $33 \%$ \\
Siswa yang Accuracy $<75 \%$ & $22(61 \%)$ & $4(11.11 \%)$ \\
Siswa yang Accuracy $\geq 75 \%$ & $14(39 \%)$ & $32(88.89 \%)$ \\
Ketuntasan (\%) & $38.89 \%$ & $88.89 \%$ \\
\hline
\end{tabular}

Gambaran mengenai deskripsi rata-rata pencapaian siklus I dan siklus II hasil belajar biologi dengan PjBL Berbasis Mind Mapping dapat dilihat pada Gambar 1. di bawah ini.

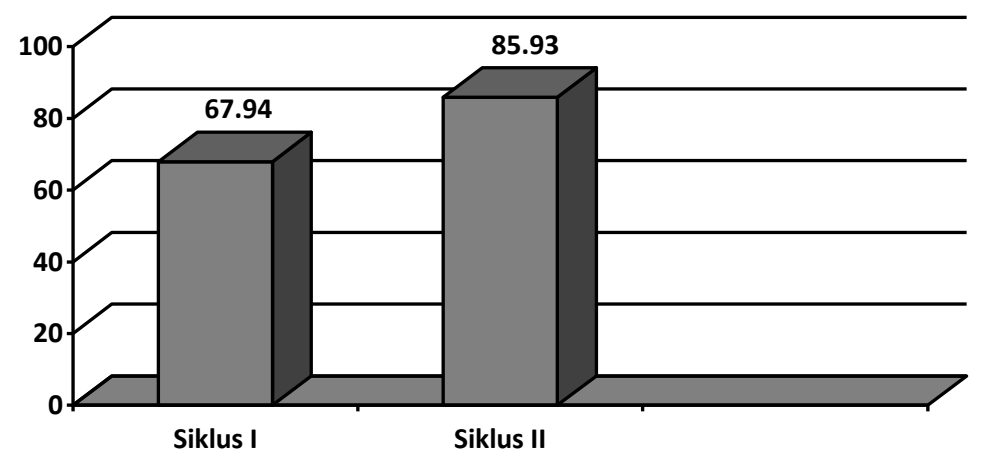

Gambar 1. Histogram Perbandingan Rata-Rata Hasil Belajar Biologi Siklus I dan Siklus II

Dalam penelitian ini terlihat perbedaan yang nyata pada hasil belajar biologi antara siklus I dan siklus II, disebabkan karena dengan pembelajaran PjBL berbasis mind mapping membuat siswa semakin terpupuk sikap mandirinya. Karena pada dasarnya PjBL menuntut siswa untuk belajar menemukan ilmunya sendiri dalam karya, mereka diajak merancang proyek mereka sendiri, diajak menentukan lama waktu pengerjaan dan diajak melakukan kesepakatan dari awal tentang hal-hal yang berkaitan dengan proyek mereka. Pembelajaran Berbasis Proyek (Project Based Learning=PjBL) menurut Kemendikbud (2014) adalah model pembelajaran yang menggunakan proyek/kegiatan sebagai inti pembelajaran. Sedangkan menurut Joel L (2009 dalam Widyantini, 2014) Pembelajaran berbasis proyek adalah strategi 
pembelajaran yang memberdayakan siswa untuk memperoleh pengetahuan dan pemahaman baru berdasar pengalamannya melalui berbagai presentasi. PjBL merupakan model belajar yang menggunakan masalah sebagai langkah awal dalam mengumpulkan dan mengintegrasikan pengetahuan baru berdasarkan pengalamannya dalam beraktifitas secara nyata. Menurut (Aisah, 2014) Keuntungan Pembelajaran Berbasis Proyek: (1) Meningkatkan motivasi belajar peserta didik untuk belajar, mendorong kemampuan mereka untuk melakukan pekerjaan penting, dan mereka perlu untuk dihargai, (2) Meningkatkan kemampuan pemecahan masalah, (3) Membuat peserta didik menjadi lebih aktif dan berhasil memecahkan problem-problem yang kompleks, (4) Meningkatkan kolaborasi, (5) Mendorong peserta didik untuk mengembangkan dan mempraktikkan keterampilan komunikasi, (6) Meningkatkan keterampilan peserta didik dalam mengelola sumber, (7) Memberikan pengalaman kepada peserta didik pembelajaran dan praktik dalam mengorganisasi proyek, dan membuat alokasi waktu dan sumbersumber lain seperti perlengkapan untuk menyelesaikan tugas, (8) Menyediakan pengalaman belajar yang melibatkan peserta didik secara kompleks dan dirancang untuk berkembang sesuai dunia nyata, (9) Melibatkan para peserta didik untuk belajar mengambil informasi dan menunjukkan pengetahuan yang dimiliki, kemudian diimplementasikan dengan dunia nyata, dan (10) Membuat suasana belajar menjadi menyenangkan, sehingga peserta didik maupun pendidik menikmati proses pembelajaran.

Dari awal PjBL sudah merangsang daya pikir mereka untuk merancang hal yang sifatnya kedepan. Dengan diberikan kesempatan pada siswa untuk menentukan batas waktu pengerjaan proyek diharafkan juga dapat memupuk rasa tanggung jawab siswa terhadap sebuah kesepakatan yang sebelumntya telah dibuat di awal. Ditambah lagi PjBL dalam penelitian ini diberikan muatan mind mapping maka daya kreasi siswa semakin meningkat, karena dalam proses pembuatan mapping iimajinasi siswa akan terus teangsang unuk bertumbuh, karena siswa dikondisikan dalam suasanan menyenangkan, melakukan apa yang senang mereka lakukan. Misalnya siswa yang senang menggambar maka hobi menggambarnya bisa tersalurkan karena dalam pembuatan mapping bahasa diperbolehkan diganti gambar yang penting memiliki makna yang sama, siswa juga lebih senang belajar karena diberikan kebebasan dalam berkespolorasi menggunakan warna. Karena dengan warna yang beranekaragam dapat merangsang keceriaan dan kebahagiaan batin. Dalam suasana yang menyenangkan maka siswa tidak akan merasa tertekan dalam belajar.

Segala upaya yang dilakukan dalam proses pembelajaran apakah mempariasikan metode atau model pembelajaran tidak terlepas dari tujuan pendidikan yang ingin dicapai yaitu peningkatan hasil belajar. Selain meningkatkan kreativitas, antusiasme siswa dalam belajar, penelitian ini terbukti dapat meningkatkan hasil belajar siswa. Karena dapat dilihat dari pengertian belajar. Belajar adalah suatu proses usaha yang dilakukan seseorang untuk memperoleh suatu perubahan tingkah laku yang baru secara keseluruhan, sebagai hasil pengalaman sendiri dalam interaksi dengan lingkungannya. Dimana dalam penelitian ini yang baru diukur adalah peningkatan hasil belajar kognitif. Menurut teori perkembangan kognitif dari Piaget yang dikenal dengan teori konstruktivisme (construction) menyatakan bahwa kecerdasan atau kemampuan kognitif seorang anak mengalami kemajuan melalui empat tahapan yang jelas. Masing-masing tahapan dicirikan oleh kemunculan kemampuan-kemampuan baru dan cara mengolah informasi. Adapun tahapan teori ini adalah: 1) Masa Infancy; 2) Pra Sekolah; 3) Anak-anak; 4) Remaja. Setiap tahapan ini mempunyai ciri dari struktur kognitif umum yang mempengaruhi semua pemikiran anak. Ada beberapa hal yang dapat dipetik dari teori belajar Piaget yang diadaptasi dari (Swadarma, 2013) (1) Belajar untuk mengatasi, merekontruksi, dan menemukaan jawaban sendiri bagi siswa akan berhasil lebih baik apabila dilakukan dengan metode pengajaran tanpa paksaan; (2) Manusia membangun kemampuan kognitifnya dengan tindakan yang terstimulus dengan sendirinya terhadap lingkungannya; (3) Kognitif adalah proses yang terjadi secara internal di dalam pusat susunan saraf pada waktu manusia sedang berpikir; dan (4) Kecerdasan merupakan kemampuan melakukan operasi logis yang berdasarkan pada realita. Berdasarkan hal tersebut ada kesesuaian teori Piaget dengan PjBL adalah sebagai berikut: (1) Dengan proyek mind mapping, peserta didik dapat mengungkapkan ide mereka berdasarkan pengetahuan yang telah diperoleh sebelumnya, sesuai dengan kreativitas masing-masing; (2) Memberi kesempatan kepada peserta didik untuk mengemukakkan gagasan dengan bahasanya sendiri; (3) Memberi kesempatan kepada peserta didik untuk berpikir tentang pengalamannya sehingga menjadi lebih kreatif dan imajinatif; (4) Memberi kesempatan kepada peserta didik untuk mencoba gagasan baru; (5) Memberi pengalaman yang berhubungan dengan gagasan yang telah dimiliki peserta didik; dan (6) Mendorong peserta didik untuk lentur terhadap perubahan gagasan.

\section{Simpulan dan Saran}

Berdasarkan hasil analisis data dan pembahasan yang telah diuraikan dapat dirumuskan simpulan: Penerapan Projek Based Learning (PjBL) Berbasis Mind Mapping dapat meningkatkan hasil belajar siswa 
kelas XI MIPA 2 SMA Negeri 1 Semarapura semester genap tahun pelajaran 2019/2020 di masa isolasi mandiri Covid-19.

Berdasarkan temuan-temuan yang diperoleh dalam penelitian ini, maka dapat diajukan saran-saran sebagai berikut: 1) Untuk guru dalam usaha memperoleh hasil belajar biologi yang optimal, guru sebaiknya menyiapkan perangkat pembelajaran lebih awal, melaksanakan pembelajaran dengan menyenangkan dengan memberikan waktu pada peserta didik lebih banyak untuk berdiskusi dan menggali ilmunya sendiri dengan panduan LKS yang sudah diberikan lebih awal, memperhatikan kreativitas peserta didik, lebih sabar menghadapi berbagai persoalan yang ditanyakan oleh peserta didik, karena dalam PjBL berbasis Mind Mapping lebih menekankan pada kreatifitas peserta didik sedangkan guru hanya berfungsi sebagi pasilitator dalam proses pembelajaran. Serta seorang guru memerlukan kesiapan dan inovasi model pembelajaran jika tiba-tiba proses pembelajaran mengalami perumahan seperti masa pendemi Covid-19,2) Diharapkan peserta didik dapat belajar untuk meningkatkan kualitas intelektual dan kreativitas serta siap dengan peruahan proses pembelajaran yang terkadang bias berubah misalnya karena wabah penyakit, bencana alam dan kasus-kasus lainnya. Dengan kemampuan intelektual yang dikuasai maka peserta didik nantinya akan bisa bersaing di dunia kerja. Sedangkan dengan kreativitas yang terlatih maka peserta didik nantinya akan bias menunjukan prestasi kerja dengan mampu melaksanakan semua tanggung jawab yang diberikan dengan baik, dan 3) Lembaga dan pengelola sekolah terutama kepala sekolah dan komite supaya menyiapkan anggaran yang cukup guna terus-menerus meningkatkan sarana-perasarana sekolah dan meningkatkan kualifikasi guru-gurunya. Selain itu pengelola sekolah siap dengan inovasi sarana prasarana apabila tiba-tiba peroses pembelajaran tidak bisa dijalankan seperti biasa dari yang tatap muka menjadi daring, misalnya dengan menyiapkan kuota internet untuk guru dan siswa, karena tidak semua siswa memiliki orang tua yang berpenghasilan berlebih untuk mendukung biaya untuk pembelajaran online. Dengan sarana-perasarana yang memadai dan guru-guru yang profesional, maka hasil belajar peserta didik akan dapat tercapai secara optimal.

\section{Daftar Rujukan}

Aisah. 2014. Kelebihan dan Kelemahan Model Pembelajaran Berbasis Proyek (Project Based Learning). Tersedia pada: kerjaonline-aisah.blogspot.com. Diunduh 14 April 2020

Anderson, L.W. \& Krathwohl, D.R. 2001. A Taxonomy For Learning, Teaching, and Assessing. New York

DePorter, B \& Hernacki, M. 2013. Quantum Learning: Membiasakan Belajar Nyaman dan Menyenangkan. Penerjemah: Alwiyah Abdurrahman. Edisi I. Bandung: Kaifa.

Hidayat, Heri, Heny Mulyani, Ajeng Siti Fatimah, Amallia Sholihat, Ana Zulfia Latifah. 2020. Penerapan Metode Mind Mapping untuk Meningkatkan Kreativitas pada Pembelajaran Pendidikan Kewarganegaraan. Jurnal Pendidikan, Volume 21, Nomor 1, Hal. 38-50. Tersedia Pada: http://jurnal.ut.ac.id/index.php/jp/article/download/546/727/.

Jihad, A. \& Haris, A. 2012. Evaluasi Pembelajaran. Cetakan I. Yogyakarta; Multi pressindo.

Menteri Pendidikan dan Kebudayaan. 2014. Materi Pelatihan Guru Implementasi Kurikulum 2013 Tahun Ajaran 2014/2015: Mata Pelajaran Biologi SMA/SMK. Jakarta. Badan Pengembangan Sumber Daya Manusia Pendidikan dan Kebudayaan dan Penjaminan Mutu Pendidikan Kementerian Pendidikan dan Kebudayaan.

Nurani, Indah Wahyu, Wakidi dan Yustina Sri Ekwandari. 2014. Pengaruh Model Pembelajaran Mind Mapping terhadap Hasil Belajar Sejarah Siswa. PESAGI (Jurnal Pendidikan dan Penelitian Sejarah), Vol 2 No 2 Hal. 1-12. Tersedia Pada: http://jurnal.fkip.unila.ac.id/index.php/PES/article/view/4960/pdf_58.

Prastyo, A. (2016). Pengaruh Metode Mind Mapping Terhadap Kreativitas Belajar Siswa Kelas V Pada Mata Pelajaran Matematika Di Sd Negeri Banyuanyar 1 Surakarta Tahun Pelajaran 2016/2017. Jurnal PGSD. Uviversitas Slamet Riyadi. http://jurnal.ut.ac.id/index.php/jp/article/download/546/727/.

Swadarma, D. 2013. Penerapan Mind Mapping Dalam Kurikulum Pembelajaran. Jakarta: Elex Media Komputindo.

Syam, Natriani, Ramlah. 2015. Penerapan Model Pembelajaran Mind Mapping dalam Meningkatkan Hasil Belajar pada Mata Pelajaran Ilmu Pengetahuan Sosial Siswa Kelas IV SDN 54 Kota Parepare. Jurnal 
Publikasi Pendidikan, Vol. 5 No. 3 Hal. 184-197. Tersedia Pada: http://ojs.unm.ac.id/index.php/pubpend.

Widyantini, T. 2014. Penerapan Model Project Based Learning (model Pembelajaran Berbasis Proyek) dalam materi Pola Bilangan Kelas VII. Artikel (PDF). Tersedia pada: p4tkmatematika.org/. diunduh:16 Juni 2015 